\title{
Imagem e Imaginário como componentes da construção da Experiência Turística do viajante ${ }^{[1]}$
}

\begin{abstract}
Image and Imaginary as components of the construction of the Tourist Experience of the traveler
Imagen e Imaginario como componentes de la construcción de la Experiencia Turística del viajero
\end{abstract}

Fabiola Fernandes Silva

Universidade Federal do Rio Grande do Norte (UFRN),

DOI: https://doi.org/10.18472/cvt.19n2.2019.1389

Redalyc: http://www.redalyc.org/articulo.oa?

Brasil

$\mathrm{id}=115460585002$

fabiola_fsd@yahoo.com.br

Leandro Tavares Bezerra

Universidade Federal do Rio Grande do Norte (UFRN),

Brasil

thavaresleandro@hotmail.com

Wilker Ricardo de Mendonça Nóbrega

Universidade Federal do Rio Grande do Norte (UFRN),

Brasil

wilkernobrega@yahoo.com.br

Recepção: 03 Janeiro 2017

Aprovação: 25 Fevereiro 2019

\section{Resumo:}

As experiências que o indivíduo constrói no destino de sua viagem advêm de um conjunto de elementos, entre eles a imagem e o imaginário individual ou grupal. $\mathrm{O}$ intuito deste trabalho é discutir como a experiência do viajante é alimentada por meio de imagens e imaginários do local, antes, durante e depois de sua viagem. A metodologia utilizada foi a realização de um levantamento teórico por meio da revisão da literatura existente sobre a imagem e o imaginário do viajante, como forma de entender essa relação e sua possível ligação com as experiências advindas da atividade turística. Constata-se que a partir dos pressupostos teóricos conceituais, a formação da imagem do destino turístico é influenciada pelas experiências dos turistas, que, por sua vez, são compartilhadas entre os viajantes, divulgando imagens que passam a alimentar o imaginário, afetando assim as experiências do indivíduo. O presente estudo ampliou a compreensão sobre a construção da experiência turística e suas transgressões apresentadas na sociedade industrializada e informatizada.

PALAVRAS-CHAVE: Imagem, Imaginário, Viajantes, Experiências Turísticas.

\section{Abstract:}

The experiences that the individual constructs in the destiny of his trip comes from a set of elements, among them the image and the individual or group imaginary. The purpose of this work is to discuss how the traveler's experience is fed through imagery and imagery of the place, before, during and after his trip. The methodology used was to carry out a theoretical survey through the review of the existing literature on the image and the imaginary of the traveler, as a way of understanding this relation and its possible connection with the experiences coming from the tourist activity. It is observed that from the conceptual theoretical assumptions, the image formation of the tourist destination is influenced by the experiences of the tourists, who in turn are shared among the travelers, disseminating images that feed the imagination and affect the experiences of the individual. The study has broaden the understanding on the construction of the tourist experience and its transgressions presented in the industrialized and computerized society.

KEYWORDS: Image, Imaginary, Travelers, Tourist Experience.

\section{RESUMEN:}

Las experiencias que el individuo construye sobre el destino de su viaje se producen a partir de una serie de factores, incluyendo la imagen y la imaginación individual o en grupo. El objetivo de este trabajo es discutir cómo la experiencia del viajero es alimentado por imágenes y el sitio imaginaria antes, durante y después de su viaje. La metodología utilizada fue la realización de un estudio teórico mediante la revisión de la literatura existente sobre la imagen y el viajero imaginario, como una manera de entender esta 
relación y su posible relación con las experiencias que surgen de turismo. Parece que a partir de los supuestos teóricos conceptuales, la formación de la imagen destino turístico se ve influenciada por las experiencias de los turistas, que a su vez son compartidos entre los viajeros, la difusión de imágenes que vienen a alimentar el imaginario afectando así las experiencias del individuo. El estudio amplio la comprensión de la construcción de la experiencia turística y sus transgresiones presentado en sociedad industrializada e informatizado.

Palabras ClaVe: Imagen, Imaginario, Los viajeros, Experiencia de Turismo.

\section{INTRODUÇÃO}

As experiências proporcionadas pela atividade turística são assuntos pesquisados entre muitos teóricos da área do turismo que buscam compreender principalmente a relação entre o turista e a vida cotidiana. Essa relação já despertou e vem despertando o interesse de autores como Krippendorf (2003), MacCannell (2003), Uriely (2005), entre outros. Esses autores debruçam-se nessa temática por entender que de modo geral é necessário investigar não apenas os embates mercadológicos do turismo, mas também as relações que essa atividade desperta na sociedade, principalmente mediante os avanços tecnológicos. Esses avanços permitem a propagação e disseminação das imagens de destinos turísticos do mundo todo, como também fortificam a relação do indivíduo com o local para o qual se deseja viajar.

A imagem representa um instrumento importante para a realização da atividade turística, estando presente antes do momento da escolha do destino da viagem até o momento após a viagem ter sido concretizada. Por meio das imagens registradas são condensados sentimentos imaginais do indivíduo e do local visitado. Autores como Gastal (2005) e Silva (2006) trabalham essas relações e consolidam os conceitos de imagens e imaginários.

Analisar a ligação entre a imagem e o imaginário e entender as contribuições de ambos para o desenvolvimento de um destino turístico é algo complexo tão quanto contemporâneo. É necessário entender que a imagem em seu sentido mais amplo tal como o imaginário não são características exclusivas da pósmodernidade, uma vez que essa relação esteve presente desde tempos mais remotos, como nas viagens realizadas no século XVII pelos filhos de famílias aristocráticas com objetivos pedagógicos conhecidas como Grand Tour. Os relatos vivenciados nessas viagens já despertavam no próximo a busca do querer viajar. As imagens vistas, as paisagens pintadas e narradas de um indivíduo para o outro já traçavam a relação entre imagem e imaginário.

Sob essa perspectiva, o objetivo geral deste estudo é discutir como a experiência do indivíduo é alimentada por meio de imagens e imaginários do local, antes, durante e depois de sua viagem. A relação imagem, imaginário e viajante será abordada para discutir a construção da experiência turística, avaliando os pontos mais significativos e as ligações com os valores subjetivos existentes durante a viagem.

Para alcançar o propósito da pesquisa, compreender as relações supracitadas, assim como contribuir com os estudos referentes à teoria da experiência turística, foi realizado um levantamento teórico por meio da revisão da literatura sobre a imagem e o imaginário, a fim de entender as experiências do viajante advindas da atividade turística. A revisão bibliográfica foi realizada em livros e periódicos da área turística e das áreas correlatas, nacionais e internacionais. Todavia, esse trabalho debruça-se a discutir turismo, experiência, imagem e imaginários das viagens na busca da compreensão à luz da pós-modernidade, em que as relações sociais e culturais são observadas com maior amplitude, como na obra de Uriely (2005).

Como forma de oferecer embasamento teórico a essa discussão, inicialmente são discutidos turismo, viagem e experiência; em seguida será abordada a relação entre o turismo e as imagens. Na sequência, é apresentada a construção do imaginário na experiência turística, encerrando com as considerações finais. 


\section{TURISMO, VIAGEM E EXPERIÊNCIA}

As viagens, de um modo geral, geram uma experiência positiva ou negativa. Para que haja uma experiência positiva e marcante durante uma viagem, há necessidade, como cita Trigo (2010), de superar a banalidade, os aspectos triviais, estereotipados e convencionais e estruturar-se como uma experiência que nasça da riqueza pessoal do viajante em busca de momentos e lugares que enriqueçam sua história. Caso contrário, sobrará a promessa não cumprida, a frustração, uma felicidade dúbia contaminada pela incompreensão dos paradoxos e contradições inerentes ao nosso mundo.

Diante desse ponto de vista, busca-se entender a experiência em seu contexto amplo, como um elemento desejado pelo turista, como uma forma de enaltecer a viagem. Em seu sentido etimológico, a experiência é uma palavra derivada do latim experientia - ensaio, prova, tentativa. De acordo com Altunel e Erkut (2015), o conceito de experiência é considerado um antecedente de intenções comportamentais. A experiência é particular e íntima de cada pessoa e essencial para a socialização, o aprendizado, a articulação profissional e a satisfação pessoal (PANOSSO NETTO; GAETA, 2010). A experiência é vista como um acontecimento que deixa uma impressão na mente (MA et al., 2013). Portanto, a palavra experiência não deve ser confundida com entretenimento, pois não se trata simplesmente de entreter as pessoas, mas de engajá-las no processo (COELHO; RIBEIRO; FONTES FILHO, 2007), nem se deve, todavia, confundi-la com sensação. A sensação é dada ao homem somente por sua relação com o objeto externo. A essa relação os psicólogos chamam de percepção (PANOSSO NETTO; GAETA, 2010).

Para Panosso Netto e Gaeta (2010), viajar é a experiência paradigmática, o modelo de uma experiência genuína e direta que transforma a pessoa que a realiza. Para Figueiredo e Ruschmann (2004), a viagem é uma necessidade transformadora. A viagem como experiência deve ser um desfrute, e o prazer dessa experiência é intransferível (NASCIMENTO; MAIA; DIAS, 2012). De acordo com Figueiredo e Ruschmann (2004, p. 181):

O dispêndio não produtivo, em consonância com a noção de dépense, de Georges Bataille, apropriada por Maffesoli (1989, 2000), indica a valorização da experiência turística não como uma experiência transformadora, em busca da autenticidade, como sugere MacCannell (2003), mas uma experiência que se encerra em si própria. Sem o objetivo de existir, como as festas em momentos não cotidianos, a viagem turística é uma forma completa de experiência prazerosa.

Ainda de acordo com Figueiredo e Ruschmann (2004), utilizando como referência Featherstone (1997), Urry (1990) e MacCannell (1992) alegam que não importa ao turista se o que lhe está sendo apresentando é algo autêntico ou simulação, quer seja de uma festa tradicional ou de um outro comportamento qualquer do nativo. O que importa é a qualidade e a intensidade do espetáculo que lhe permitem viver momentos prazerosos, antes, durante e depois do ato de viajar (FIGUEIREDO; RUSCHMANN, 2004). Assim, a viagem vai sofrendo influência anterior e posterior. De acordo com Pezzi e Vianna (2015), a viagem pode se iniciar antes da saída, com os preparativos e a busca de informação sobre o destino, e a posteriori quando o indivíduo retorna e relembra da viagem por meio de relatos, fotos e vídeos, como argumenta Krippendorf (2003, p. 39): “[...] os amigos e conhecidos, os vizinhos e colegas voltam das férias e contam-nos suas aventuras como se não existisse nada de mais belo sobre a terra".

Sun Tung e Ritchie (2011, p. 1369) definem experiência turística como sendo "uma avaliação individual subjetiva (afetiva, cognitiva e comportamental) de eventos relacionados à sua atividade turística que começa antes (planejamento e preparação), durante (no destino), e depois da viagem (o recolhimento)". A experiência turística inclui tudo o que um turista passa por um destino como experiência, incluindo comportamento, percepção, cognição e emoções explícitas ou implícitas (BOSANGIT; HIBBERT; MCCABE, 2015).

Para Krippendorf (2003), o ser humano não nasceu turista, mas sua curiosidade e a necessidade de mobilidade o fizeram um viajante buscando em um primeiro momento desbravar, descobrir e aprender 
para que em uma fase mais recente buscasse o lazer, a fuga do massificante dia a dia de trabalho e da monotonia do cotidiano. Ainda de acordo com o autor, trabalho, moradia e lazer são condições existenciais dos seres humanos no cotidiano. Parte desse lazer pode configurar-se em forma de viagem. Essa fuga da cidade possivelmente ocorre por uma falta de infraestrutura de lazer e uma busca de "consolo externo", pois descanso e férias podem ser entendidos igualmente como sair e viajar (KRIPPENDORF, 2003). O ser humano precisa de momentos de lazer, fugindo da sua vida cotidiana para que seja proporcionada uma experiência de estranhamento em que lembranças e vivências passadas sejam ressignificadas nesse indivíduo.

Essa necessidade do indivíduo de fugir do seu cotidiano em busca de novas experiências foi facilitada mediante o desenvolvimento das novas tecnologias da informação que tornaram trocas de informações e interações em escala global. Nesta era globalizada e de concorrências acirradas, a tecnologia e os produtos são copiados do dia para a noite enquanto os serviços vêm se tornando indiferenciáveis. Tentando fugir dessa intensa massificação, muitos turistas buscam por um serviço personalizado e por destinos que os ofereçam uma experiência memorável.

Pine e Gilmore (1999) apontam a experiência como principal diferencial em meio à sociedade massificada. Jensen (1999) também mostra a situação da mudança de valores econômicos da sociedade batizando essa nova era de "a sociedade dos sonhos ${ }^{[2] "}$. As teorias de Pine e Gilmore, na publicação The Experience Economy $(1999)^{[3]}$, e de Jensen, em seu livro The Dream Society (1999) ${ }^{[4]}$, evidenciam que o turista quer ser o ator de sua própria experiência, de seus sonhos no destino que escolheu. MacCannell (1976) assegura que os turistas desejam ir além do que normalmente lhes mostram. Não se satisfazem mais com o conhecimento de fachada, superficial, pois querem também participar dos bastidores dos lugares que visitam.

No mercado turístico é muito comum a compra de um pacote ser comparada à compra de um sonho. Isso pode ser explicado pelo fato de que a pessoa, ao adquirir uma viagem, está buscando mais do que uma coleção de serviços de transporte, hospedagem, entretenimento, alimentação, entre outros serviços que a ela possam ser ofertados. $\mathrm{O}$ turista busca transformar seu sonho em realidade, busca experiências únicas e autênticas e é dessa forma que a Economia da Experiência ${ }^{[5]}$ pode ser vista no contexto do turismo como interlocutora de um processo de vantagem competitiva que vem a contribuir não só para o aumento de receita individual, mas também para a maior eficiência do sistema econômico como um todo. As várias empresas de serviços que operam no destino, seus funcionários, as relações dos funcionários com os visitantes e as interações entre os clientes afetam as experiências (ALTUNEL; ERKUT, 2015). Em outras palavras, todas as atividades das quais um turista participa em uma viagem podem tornar-se experiências significativas (TAN; KUNG; LUH, 2013).

Esse fato faz com que a experiência apresente-se como um quarto setor na cadeia de valor econômico, distinta dos serviços e também difere da produção industrial. Em termos de posicionamento competitivo, Pine e Gilmore (2000) propõem a análise da Progressão de Valor Econômico da Experiência, como mostrado na Figura 1: 


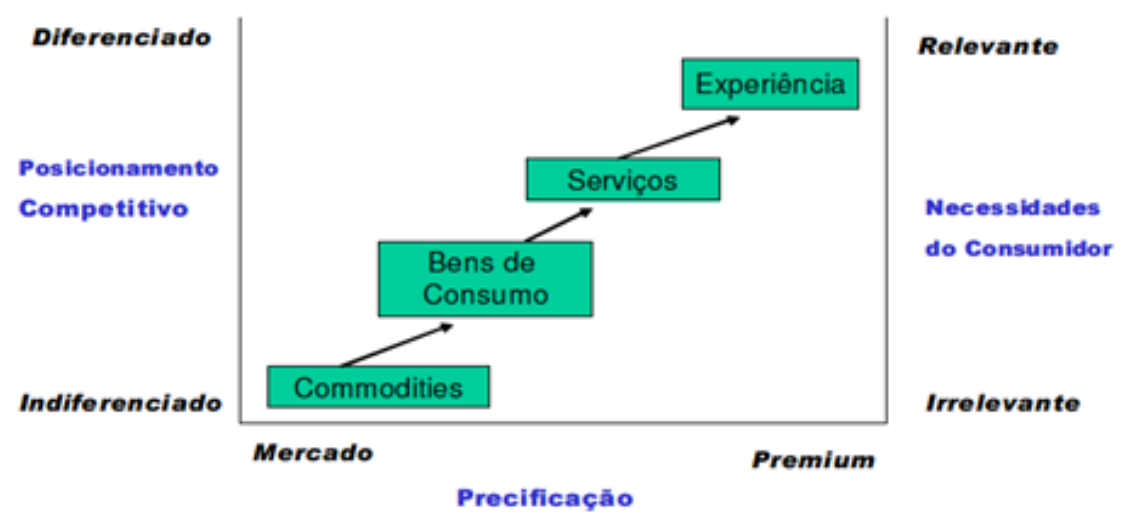

FIGURA 1

Análise da progressão de valor econômico da experiência Fonte: Pine e Gilmore (2000, p. 19).

Trata-se de um modelo evolutivo cujas variáveis são o aumento de diferenciação, relevância e preço. De acordo com Coelho, Ribeiro e Fontes Filho (2007), esse modelo parte da divisão tradicional das atividades de mercado em commodities ${ }^{[6]}$, bens de consumo e serviços e acrescentam a experiência como componente da alta capacidade de diferenciação e grau de relevância para o cliente a preço Premium ${ }^{\text {[7]. }}$

A experiência passa a adquirir um grau de relevância que vai além das commodities, bens de consumo e serviços. Trata-se da vivência do cliente com relação ao que está sendo ofertado, seja produto ou serviço. Temse uma nova necessidade do consumidor pós-moderno, que apresenta a experiência um dos elementos-chave para a escolha de compras de determinados produtos e bens de consumo.

A luta pela manutenção da lucratividade, conforme colocado por Harvey (1993), abre espaço para a exploração de possibilidades. Novos produtos, novos significados, novos desejos e necessidades são explorados pelo capital enfatizando apetites imaginários, fantasias e caprichos que são despertados por interesse de consumir. As experiências ditas como autênticas são comercializadas, e imagens de uma realidade, talvez não condizente, são criadas. A experiência adquire, além do valor de troca (trocar experiências de viagem), também o valor de uso, passando a ser comercializada e relacionada a questões econômicas dentro da atividade turística, por isso, torna-se importante discutir não apenas os embates mercadológicos da experiência, mas também as transgressões dessa experiência no cotidiano.

Os turistas escolhem um destino de acordo com atributos que consideram importantes e esses atributos influenciarão de forma significativa a formação da imagem do destino. De acordo com Tan et al. (2014), alguns estudos têm mostrado que embora a imagem do destino seja uma das mais fortes influências sobre o comportamento futuro, as experiências dos turistas afetam a formação da imagem. As pessoas podem mudar suas percepções sobre o destino após a viagem com base nas experiências no local. Observa-se uma relação entre imagem e turista como fator que conduz à experiência, uma relação criada em muitos casos por meios audiovisuais.

\section{IMAGENS FOTOGRÁFICAS E VÍDEOS COMO COMPONENTES DAS EXPERIÊNCIAS TURÍSTICAS}

Para iniciar a explanação dessa relação, faz-se necessário, antes de tudo, discorrer sobre a fotografia e sua importância para a construção da imagem do lugar. Leva-se em consideração que os turistas e suas fotografias compõem uma relação importante para a atividade turística, estetizando imagens que foram capturadas em 
suas viagens e que fazem parte das suas experiências. De acordo com Lee, Chao e Lin (2016), tirar fotos é uma forma de os turistas lembrarem de suas experiências de viagem. Para Figueiredo e Ruschmann (2004), o imaginário do turista parece que não se forma sem a presença da fotografia e dos viajantes fotógrafos, de modo que passa a ser notório quanto à fotografia, que compóe um dos elementos audiovisuais que possibilitam as experiências vivenciadas pelos viajantes.

Não é de hoje que as pessoas viajam e consigo levam suas câmeras e registram a paisagem por meio da fotografia. Porém, essa relação caracteriza-se de forma marcante no século XXI em que a civilização pósmoderna é intrínseca às imagens. Dada a importância das imagens, a fotografia tem sido uma ferramenta de expressão artística, retratando na contemporaneidade a relação turista, imagem e imaginário do destino visitado ou que se pretende visitar, uma vez que compóe esse recorte paisagístico do mundo e fornece aos indivíduos ideias subjetivas para que possam atribuir significados ao local.

As imagens invadem a vida diária e apresentam-se na relação entre o turista e a vida cotidiana. Pode-se dizer que a fotografia apresenta a sociedade estetizando uma realidade em movimento. A imagem possibilita status, e o desejo de viajar e fotografar se justapóe cada vez mais com o intuito de o viajante exibir-se e também exibir o destino no qual está vivenciando. Para Gomes (1996) apud Santos Júnior e Santos (2007, p. 6):

A imagem fotográfica, ao registrar a experiência, pode provocar novas percepçóes, produzir a subjetividade inerente ao ato de olhar do contemplador e ao mesmo tempo imortalizar o fato e o espaço captados, objetivando para o cientista aquele momento e contextualizando com outros repertórios signos do sujeito.

De acordo com esse ponto de vista, a foto é um dos elementos que compõem a construção da imagem de um determinado local e dá possibilidades de imaginá-lo, compondo também um padrão da sociedade da imagem $^{[8]}$.

Portanto, o turismo inseriu-se nessa relação não apenas por seu caráter cultural, mas também social, por se tratar de uma das atividades que está relacionada à sociedade da imagem, em que as mídias sociais presentes no século XXI são ligadas às imagens por intermédio dos usuários, que expõem imagens de suas viagens, despertando o interesse de outros indivíduos. Para Bezerra (2013, p. 26), "a imagem é como uma peça de quebra-cabeça, que possibilita distorcer a imaginação do indivíduo e é a partir dela que se tem um contato visual do local que almejará ou não visitar". As pessoas buscam entender e conhecer o local por meio das imagens que são disponibilizadas por diferentes canais de divulgações presentes na sociedade pós-moderna.

Trata-se aqui de uma mudança de paradigma da modernidade para a pós-modernidade, conforme explorada por Harvey (1993). É uma nova análise na cultura contemporânea, que permite identificar a sociedade que abarca a imagem como conteúdo marcante no século XXI. Para Debord (2003), essa nova sociedade da imagem é marcada pela espetacularização da cidade, tendo o espetáculo não como um conjunto de imagens, mas uma relação social entre pessoas mediatizada por imagens.

Para o autor, vive-se em uma sociedade marcada não apenas por imagens, mas pela espetacularização dela. Em sua obra, "A Sociedade do Espetáculo" [9], é identificada a importância da imagem na vida cotidiana.

As imagens fluem desligadas de cada aspecto da vida e fundem-se num curso comum, de forma que a unidade da vida não mais pode ser restabelecida. A realidade considerada parcialmente reflete em sua própria unidade e gera um pseudo mundo à parte, objeto de pura contemplação. A especialização das imagens do mundo acaba numa imagem autonomizada, onde o mentiroso mente a si próprio. O espetáculo em geral, como inversão concreta da vida, é o movimento autônomo do não vivo (DEBORD, 2003, p. 09).

Com o advento da internet foi facilitado o acesso de informação para as pessoas. As tecnologias passam a alimentar o viajante e passa a proporcioná-lo informações favoráveis a sua decisão de viajar. Os acessos a sites de viagens, o compartilhamento de ideias e experiências das viagens são disponibilizados sem custo entre usuários. Como dito por Maffesoli (2001), trata-se de um momento histórico em que o intenso desenvolvimento tecnológico proporciona uma experiência ao indivíduo antes mesmo da viagem acontecer, influenciando a compra do destino. 
A espetacularização da experiência do indivíduo nessa sociedade ganha espaço com as mídias sociais, destacando principalmente os blogs e algumas redes sociais, como Facebook, Instagram e Youtube. Trazemse aqui como exemplos (ver Figura 2) o blog Matraqueando (MATRAQUEANDO, 2016), que apresenta dicas de destinos e hospedagens. Tais dicas, além de serem úteis a alguns viajantes, podem influenciar a formação da imagem e do imaginário do local. O perfil no Instagram @girleatworld (GIRLEATWORLD, 2016) registra imagens de viagens de um jeito diferente, mostrando as comidas de cada lugar de frente para paisagens conhecidas do destino, e o canal no Youtube Sonia's travels (SONIASTRAVELS, 2016) conta as viagens da Sônia de forma a relatar suas experiências.

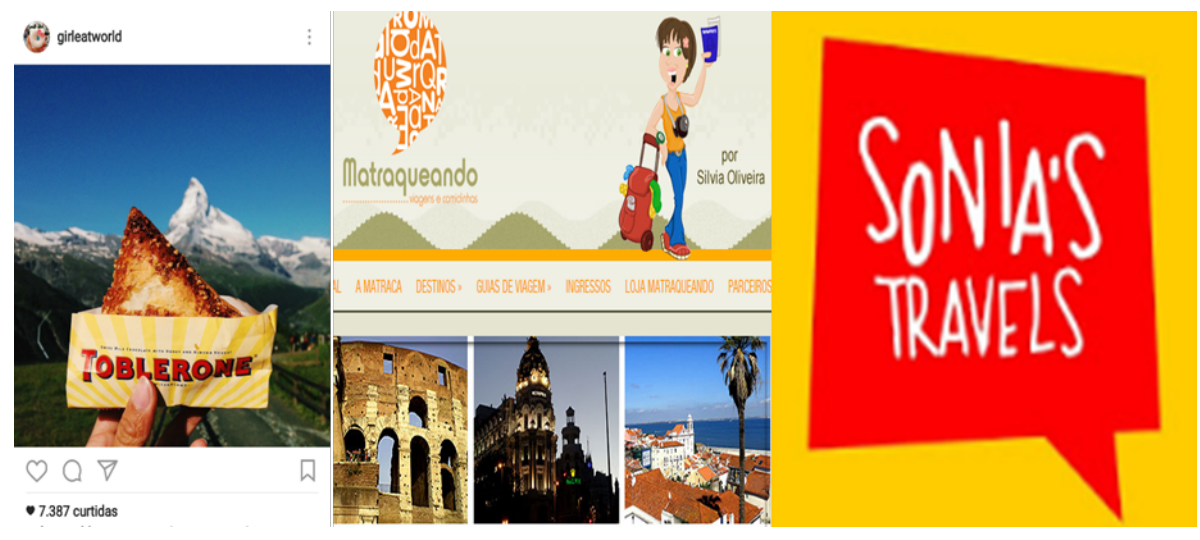

FIGURA 2

Exemplos de espetacularização por meio de ferramentas on-

line da experiência do indivíduo na contemporaneidade

Fonte: Dados da pesquisa (2016), baseado em: Site Matraqueando (http://www.matraqueando.com.br/); Canal Sonia's

Travels (https://www.youtube.com/user/soniastravels) e @girleatworld (https://www.instagram .com/girleatworld).

De acordo com a Figura 2, observa-se que a imagem flui na vida urbana e interpassa uma relação entre o local visitado e o visitante, compondo uma relação do visitante com o destino e aprofundando sentimentos que se voltam não apenas a sua subjetividade. Embora a cidade possa ser um teatro vivido de dramas, como mencionado por Harvey (1993), onde vilãos e tolos se misturam, é nela que as relações perante a sociedade vão sendo construídas. Lembranças e imagens vão se misturando e dando forma à cidade e despertando anseios e desejos de quem pretende visitá-la. Para Debord (2003), a cidade depende das superfícies e aparências que são criadas pelo indivíduo por intermédio das relações sociais, isso é o que a compõe.

Assim, a vida cotidiana vai tomando forma, os viajantes vão construindo a imagem de uma cidade e, com isso, criando uma identidade para ela. As imagens se configuram em informações da localidade. É nesse momento que a relação imagem, imaginário e viajante é encontrada. Trata-se de uma relação ligada pela atividade turística, que, para ser compreendida, faz-se necessário entender sua conexão com o imaginário.

\section{A CONSTRUÇÃO DO IMAGINÁRIO NA EXPERIÊNCIA TURÍSTICA}

Quando se fala em imaginário remete a muitos um mundo de fantasias, ilusões e pensamentos. Porém, para Gastal (2005), o imaginário seria o sonho que realiza a realidade, uma força que impulsiona indivíduos ou grupos. Seria um motor que produz força ao início de uma jornada, fornece rumo a uma viagem de imaginaçóes do viajante e o proporciona a busca do conhecimento sobre o local para o qual se pretende viajar. De acordo com Salazar (2012), imaginário é uma reunião de representações sociais transmitidas socialmente que interagem com a imaginação pessoal das pessoas, sendo tanto uma função de produzir significados como o produto dessa função. 
Para Silva (2006, p. 12), "o imaginário é uma distorção involuntária do vivido que se cristaliza como marca individual ou grupal. Diferente do imaginado, projeção irreal que poderá se tornar real, o imaginário emana do real, estrutura-se como ideia e retorna ao real como elemento propulsor". O autor enfatiza afirmando que:

Motor, o imaginário é um sonho que realiza a realidade, uma força que impulsiona indivíduos ou grupos. Funciona como catalisador, estimulador e estruturador dos limites das práticas. O imaginário é uma marca digital simbólica do indivíduo ou do grupo na matéria do vivido. Como reservatório, o imaginário é essa impressão digital do ser no mundo. Como motor, é o acelerador que imprime velocidade à possibilidade de ação. O homem age (concretiza), porque está mergulhado em correntes imaginárias que o empurram contra ou a favor do vento (SILVA, 2006, p. 12).

Há uma tendência ao desenvolvimento da atividade turística estar atrelada ao imaginário das pessoas, já observada há algum tempo, como, por exemplo, no Grand Tour e na literatura romântica que despertavam o interesse e desejo por conhecer in loco o que era descrito pelos autores. Para Salazar (2012), é difícil imaginar o turismo sem o uso criativo de sedutores imaginários sobre povos e lugares. Gastal e Castrogiovanni (2003, p. 57) afirmam que "não viajamos para conhecer os lugares, mas para confirmar o imaginário que temos dele".

O indivíduo, ao falar do local de sua viagem, concretiza a ideia de que todo imaginário é real e vice-versa, pois, de acordo com Bezerra (2013), o ser humano crê e se apega às imaginações, como uma maneira de ter um contato mesmo que imaginário do mundo real, vislumbrando o contato inicial com seu destino final, ou seja, o local de sua viagem. É dessa maneira que funciona o imaginário humano e é dessa mesma forma que se justapõe ao turismo.

Para Barbas e Graburn (2012, p. 03), “o imaginário dos lugares, dos destinos e das viagens é produzido e consumido por diversas populações em todo o globo, notadamente por meio dos papéis crescentes das mídias e das oportunidades de viajar”. Esses fatores, influenciados pelos avanços tecnológicos, proporcionam cada vez mais a atividade turística, que desperta desejo do viajante em busca de locais ainda não visitados, reconhecidos como autênticos, que possibilitem transmitir ao viajante uma experiência única, proporcionando uma fuga do cotidiano.

MacCannell (1976) defende que existe essencialmente a busca religiosa da autenticidade do destino. A experiência é vista como a busca do novo, seja de destino ou sensações. Essa busca é marcada por imaginários da realidade vivida e registrada por fotos que estetizam o momento da experiência e que remetem à memória do indivíduo após a viagem, aderindo também à questão da subjetividade que lhe fará diferenciar uma experiência da outra.

De acordo com Uriely (2005), a noção atual da experiência turística como um fenômeno diverso é acompanhada pela ideia de que a atenção é deslocada a partir dos objetos exibidos para o turista, gerando percepções subjetivas de significados como determinante da experiência. É dessa maneira que as relações complexas da atividade turística ocorrem e a sociedade da imagem se atrela ao turismo, despertando no turista o imaginário de lugares e sensações que podem ser obtidas a partir das viagens.

As viagens estão presentes em imagens, como, por exemplo, nas ações capturadas no tempo e espaço que trazem lembranças, desejos e anseios, adquirindo valores subjetivos para determinar se a imagem de um dado lugar é melhor, mais atraente, mais desejada que outras, e, assim, gerar o formato da imagem de lugares a partir de um imaginário em que outrora era individual, passando a ser grupal, caracterizando dessa forma, o lugar visitado. Para Falco (2011) apud Bezerra (2013, p. 27):

A sociedade contemporânea assiste a um jogo de complexidades que modifica sua forma de ser e de estar no mundo, bem como seus aparatos de construção e reconstrução dos imaginários. Nesse momento, marcado pelo surgimento de novas tecnologias e pelo ressurgimento de antigas necessidades humanas, os meios de comunicação e as viagens passam a ser também encarados a partir de novos paradigmas de compreensão social. Nesse contexto, as cidades para serem consideradas turísticas necessitarão, cada vez mais, dos aparatos midiáticos para chegarem a fazer parte dos sonhos, imaginários, planos e agendas dos turistas.

Maffesoli (2001, p. 76) afirma que "o imaginário de Paris faz Paris ser o que é. Isso é uma construção histórica, mas também o resultado de uma atmosfera e, por isso mesmo, uma aura que continua a produzir 
novas imagens". A Paris romântica e das luzes é um dos destinos mais visitados do mundo. Já a Paris das ruas sujas com os dejetos dos animais de estimação e das pessoas distantes desaparece da construção de um imaginário formado pelos agentes que promovem o destino (AZEVEDO, 2011).

Outro exemplo, de acordo com Azevedo (2011), é o estado de Pernambuco, que possui um imaginário ibero-barroco, com forte valorização da cultura popular, como é mostrado na Figura 3. Várias de suas cidades possuem uma forte imagem e imaginário, como, por exemplo, Olinda, declarada Patrimônio Histórico e Cultural da Humanidade pela Unesco , com o frevo; Recife com o maior bloco de carnaval do mundo, o Galo da Madrugada; Porto de Galinhas, que é o grande destino para casais em lua de mel; Petrolina, onde há o enoturismo; o sertão com a rota do cangaço e o Arquipélago de Fernando de Noronha, onde é realizado o ecoturismo.
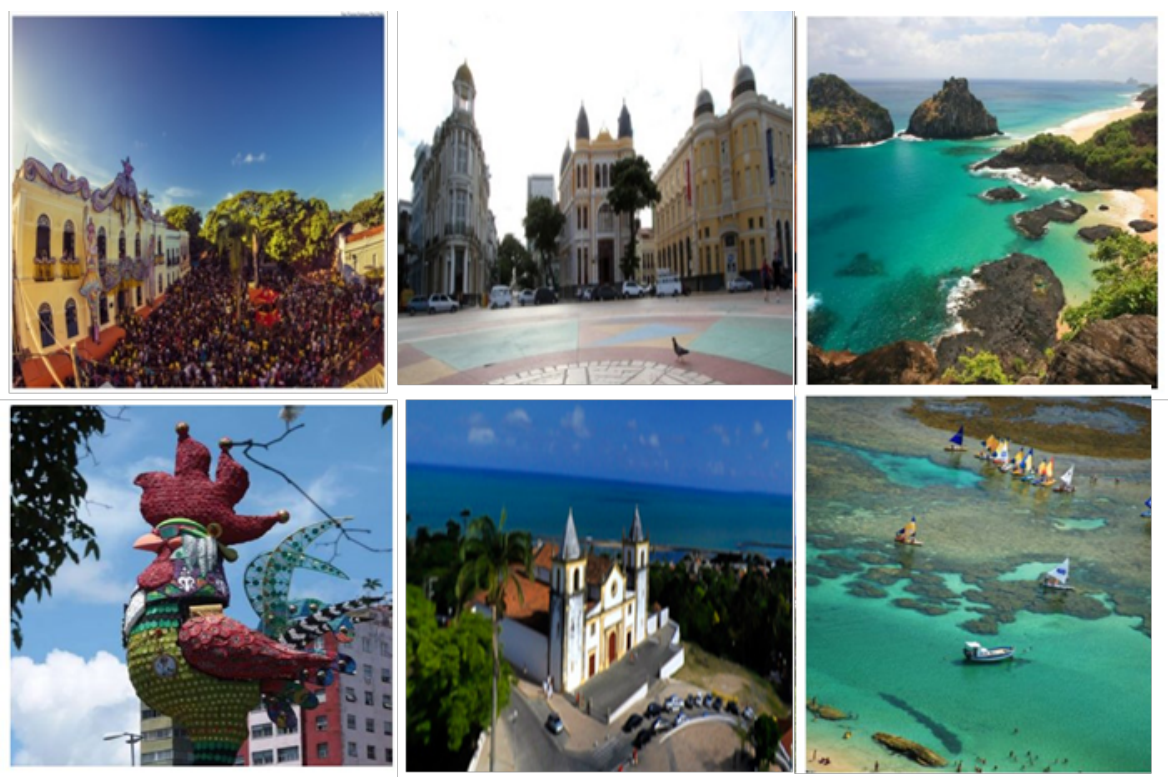

FIGURA 3

Imagens que despertam o imaginário do estado de Pernambuco

Fonte: Dados da pesquisa (2016), adaptado de Secretaria de Turismo de Pernambuco (2016)

As figuras apresentadas levam as pessoas a construírem certas significações e (res)significações sobre os lugares e as pessoas que neles residem, como, por exemplo, Olinda/PE, que consolida-se como uma cidade que desperta o interesse de visitantes para conhecer sua história, seus traços arquitetônicos, sua cultura e o seu carnaval conhecido em todo o Brasil.

Sob essa perspectiva, Barbas e Graburn (2012) afirmam que o imaginário turístico evoca uma definição multidimensional tendo em conta toda a cadeia de produção do turismo.

O imaginário está voltado para a realidade, encontrando-se profundamente enraizado nas experiências do indivíduo no local ao qual visita. Cada local desperta nos visitantes sensações diferentes dos locais anteriormente visitados e assim por diante. $\mathrm{O}$ contato com as imagens disponibilizadas por outros viajantes influenciará diretamente a consolidação da relação entre imagem, imaginário e viajante.

O imaginário permeia todo e qualquer ser humano, estando presente no ato da construção da viagem, possibilitando fantasiar a realidade que se almeja conhecer e proporcionando a construção de expectativas do viajante em relação ao destino, que pode ser bastante ou pouco visitado. Na Figura 4 é mostrada a relação entre o indivíduo, as imagens que são adquiridas por ele e como é construído o imaginário por esse viajante. 


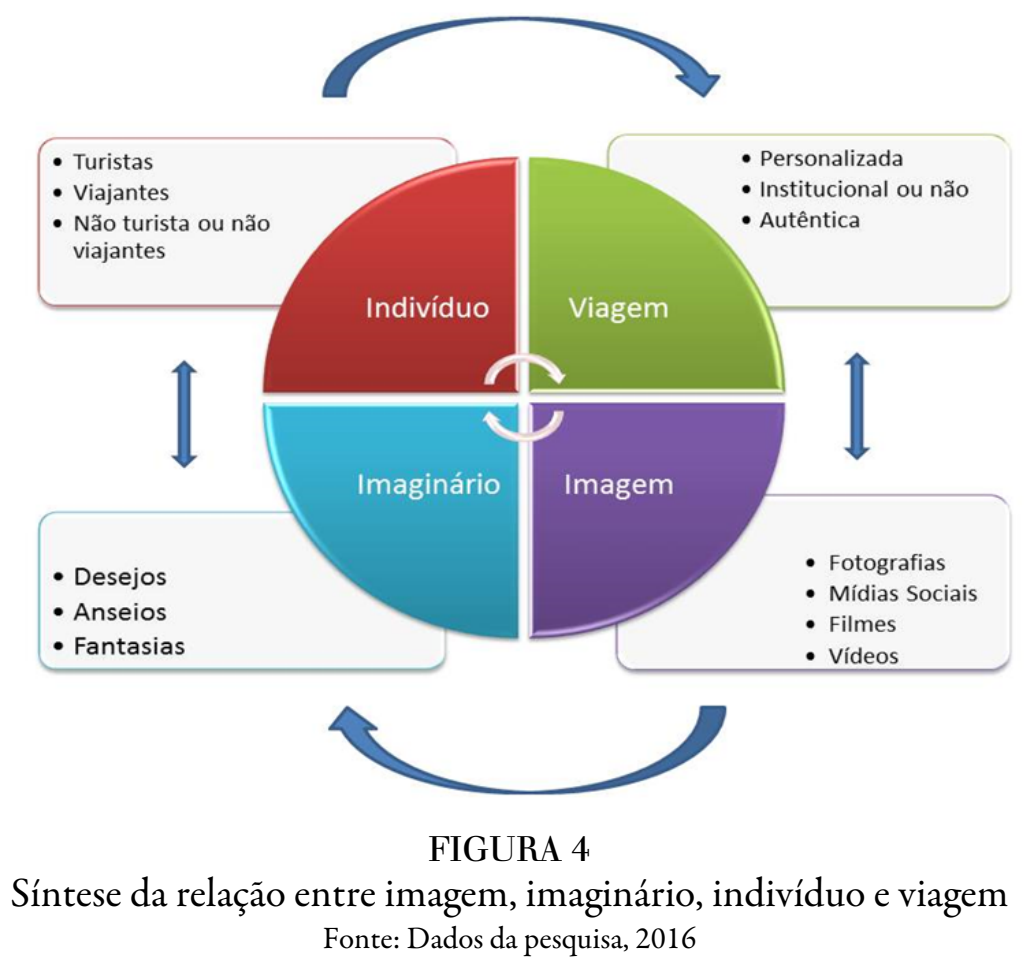

$\mathrm{Na}$ Figura 4, tem-se a síntese da relação entre imagem, imaginário, indivíduo e a viagem. Parte da ideia de Krippendorf (2003) de que o ser humano busca o lazer, a fuga do dia a dia de trabalho e da monotonia do cotidiano. Na tentativa de fugir da massificação, muitos turistas buscam por um serviço personalizado e por destinos que os ofereçam uma experiência memorável. Como solução, Jensen (1999) e Pine e Gilmore (1999) apontam a experiência e "comercialização de emoções" como principal diferencial em meio à sociedade massificada.

Ao mesmo tempo em que os turistas buscam pela autenticidade, de acordo com Figueiredo e Ruschmann (2004), não importa a eles se o que lhes está sendo apresentando é algo autêntico ou uma simulação desde que os proporcionem momentos agradáveis.

Outro ponto considerado são as imagens que invadem a vida diária e apresentam-se na relação entre o turista e a vida cotidiana, que, para Debord (2003), trata-se da sociedade da imagem, marcada pela espetacularização da cidade. Tan, Kung e Luh (2013) consideram que nesta sociedade as experiências dos turistas afetam a formação da imagem, que diz respeito a uma das mais fortes influências sobre o comportamento futuro e, portanto, item relevante para a atividade turística. Como já mencionado por Gastal e Castrogiovanni (2003), as pessoas não viajam para conhecer os lugares, mas para confirmar o imaginário que já se tem deles. Maffesoli (2001) refere-se a esse período como um momento histórico, em que a experiência do indivíduo é proporcionada antes mesmo da viagem acontecer.

Dessa forma, os elementos que compõem a Figura 4, para o contexto específico da pesquisa, são onde as relações do indivíduo ocorrem e suas experiências são executadas, ocorrendo cada um de forma individual e juntos formam parte de um conjunto, o conjunto das experiências turísticas, composto pelo indivíduo, a viagem que ele realiza, as imagens que são produzidas ou encontradas por ele e o imaginário construído do lugar da visita. 


\section{CONSIDERAÇÕES FINAIS}

Vive-se em um contexto em que a globalização torna as relações mais complexas e a competitividade mais difusa, ao mesmo tempo em que se vive em uma sociedade essencialmente contraditória. Contraditória porque consome em massa e aprecia a identidade particular, deparando-se, dessa forma, com estímulos em uma sociedade tanto informacional como emocional que busca experiências únicas e memoráveis.

Nesse panorama, o presente trabalho se propôs a discutir como a experiência do indivíduo é alimentada por meio de imagens e imaginários do local, por intermédio dos contatos prévios que os viajantes têm com o destino. As mídias sociais são exemplos de contato que proporcionam uma relação, antes, durante e depois da realização da viagem. Para tanto, foi necessário compreender o turismo pelo viés da intangibilidade e subjetividade, considerando que o indivíduo é influenciado pelas memórias e interesses particulares, mas também grupal, que interferirão na construção do imaginário de um determinado lugar.

A partir dos pressupostos teóricos conceituais da relação entre imagem, imaginário, indivíduo e a viagem, entende-se que o imaginário permeia a vida do homem, principalmente no que diz respeito às viagens, estando presente desde os primórdios da atividade turística. A formação da imagem do destino turístico é influenciada pelas experiências dos turistas, que, por sua vez, são compartilhadas entre os viajantes, divulgando imagens que passam a alimentar o imaginário de outros indivíduos e influenciando suas experiências.

Partindo dessa ideia, com relação à atividade turística, é importante que o imaginário do local seja levado em consideração tanto na fase de planejamento como na fase de comercialização. Sugere-se que o imaginário seja tratado como parte do produto turístico e não apenas um complemento ou um elemento de marketing, pois planejar não significa somente organizar o espaço físico, produtos e serviços, mas, sim, conduzir o olhar. O imaginário é o "motor" que dá o ponto de partida para as experiências ganharem formas, é dinâmico, havendo, assim, uma necessidade de alimentar o imaginário dos lugares e dos visitantes.

Diante do exposto, acredita-se que o estudo ampliou a compreensão sobre a construção da experiência turística por intermédio da imagem, do imaginário e do viajante. Tem-se de fato que o imaginário individual e grupal pode influenciar a construção da imagem de um destino por meio da propagação de relatos, fotografias, vídeos, filmes, blogs, entre outras ferramentas.

Espera-se que este estudo possa oferecer reflexões importantes sobre a experiência no contexto do turismo, dada a necessidade de se discutir as experiências advindas da atividade turística na academia, em especial aos pesquisadores que se dedicam às teorias dessa temática, e ao mercado turístico, visto que esse assunto tem impactos diretos no comportamento do consumidor no turismo.

Como principal limitação do estudo, destaca-se a divergência de opiniões sobre o tema. Para pesquisas futuras, indica-se um aprofundamento no tema, com trabalhos que se voltem a entender a relação da construção da imagem em termos fotográficos com o lugar, a relação entre o imaginário e o turista, assim como a economia da experiência, visto que esta é uma temática ampla e complexa e que pode ser reconhecida como uma chave dos estudos aplicados às relações turísticas.

Em termos mercadológicos, a experiência é tida como ferramenta da inovação e competitividade e pode consistir em um fator relevante para o crescimento dos negócios em turismo no século XXI. Contudo, ainda haverá desafios principalmente na necessidade de entender essas novas relações de consumo e a maneira de satisfazer esses desejos e fantasias. Em suma, a experiência de viagem é um atributo particular e inerente àquele que pretende realizar ou simplesmente deseja viajar.

\section{REFERENNCIAS}

ALTUNEL, M. C.; ERKUT, B. Cultural tourism in Istanbul: the mediation effect of tourist experience and satisfaction on the relationship between involvement and recommendation intention. Journal of Destination Marketing \& Management, 2015, p. 213-221. 
Fabíola Fernandes Silva, et al. Imagem e Imaginário como componentes da construção da Experiênci...

AZEVEDO, D. S. Turismo e Comunicação na Construção do Imaginário Sergipe. Intercom - Sociedade Brasileira de Estudos Interdisciplinares da Comunicação. XXXIV CONGRESSO BRASILEIRO DE CIÊNCIAS DA COMUNICAÇÃO, Recife, PE, 2011.

BARBAS, G. M.; GRABURN, N. Imaginários Turísticos. Revista Internacional Interdisciplinar de Turismo, n. 1, 2012, p. 1-5. Disponível em: http://viatourismreview.com/wp-content/uploads/2015/06/ Editorial1_PT.pdf>.. Acesso em: 29 maio 2016.

BEZERRA, L. T. Turismo e favela: a influência do imaginário para o consumo da comunidade Santa Marta / Rio de Janeiro. Monografia do curso de Turismo, Universidade Federal do Rio Grande do Norte, Natal, RN, Brasil, 2013.

BOSANGIT, C.; HIBBERT, S.; MCCABE, S. If I was going to die I should at least be having fun: travel blogs, meaning and tourist experience. Annals of Tourism Research, 55, p. 1-14, 2015.

DEBORD, G. Sociedade do espetáculo. São Paulo: eBooksBrasil, 2003. Disponível http://www.ebooksbrasil.org/ adobeebook/socespetaculo.pdf. Acesso em: maio 2016.

FEATHERSTONE, M. O desmanche da cultura. São Paulo: Studio Nobel, 1997.

FIGUEIREDO, S. L.; RUSCHMANN, D. Estudo genealógico das viagens, dos viajantes e dos turistas. Novos Cadernos Naea, v. 7, 2004, p. 171-203.

GASTAL, S. Turismo, imagens e imaginário. (Coleção ABC do Turismo). São Paulo: Aleph, 2005.

GASTAL, S.; CASTROGIOVANNI, A. Turismo na pós-modernidade: (des)inquietações. Porto Alegre: EDIPUCRS, 2003.

GIRLEATWORLD. Mel's food \& travel log (@girlatworld). Fotos e vídeos do instagram. Disponível em: https:// www.instagram.com/girleatworld/. Acesso em: 31 dez. 2016.

HARVEY, D. A condição pós-moderna. São Paulo: Ed. Loyola, 1993.

JENSEN, R. The dream society. How the coming shift from information to imagination will transform your business. New York: McGraw-Hill, 1999.

KRIPPENDORF, J. Sociologia do turismo: por uma nova compreensão do lazer e das viagens. São Paulo: Aleph, 2003.

LEE, T. H.; CHAO, W. H; LIN, H. Cultural in heritance of Hakka cuisine: a perspective from tourists' experiences. Journal of Destination Marketing \& Management, 2016.

MACCANNELL, D. The tourist: a new theory of the leisure class. Nova York: Schcken Books, 1976.

. Empty meeting grounds. The Tourist Papers. London, Routledge, 1992.

. El Turista, uma neuva teoria de la clase ociosa. Barcelona: Ed. Melusina, 2003.

MAFFESOLI, M. Sobre o nomadismo. Rio de Janeiro: Record, 2001.

MATRAQUEANDO. Matraqueando/blog de viagens por Sílvia Oliveira. Disponível em: http:// www.matraqueando.com.br/. Acesso em: 31 dez. 2016.

NASCIMENTO, I.; MAIA, A. F.; DIAS, P. O. O. A experiência como produto turístico: a emoção e a sensação do novo e diferente. Turismo: estudos e práticas - UERN, Mossoró/RN. V. 1, n. 2, 2012, p. 142-159.

PANOSSO NETTO, A.; GAETA, C. Turismo de Experiência. São Paulo: Senac, 2010.

PEZZI, E.; VIANNA, S. L. G. A Experiência Turística e o Turismo de Experiência: um estudo sobre as dimensões da experiência memorável. Turismo em Análise. V. 26, n. 1, 2015.

PINE, B. J. Personalizando produtos e Serviços - Customização Maciça. São Paulo: Makron Books, 1994.

PINE, B. J.; GILMORE, J. H. The Experience Economy. Boston: Harvard Business School Press, 1999.

. Satisfaction, sacrifice, surprise. Strategy \& Leadership, v. 28, n. 1, 2000, p. 18-23.

Welcome to the experience economy. Harvard Business Review, v. 76, n. 4, 1998, p. 97-105.

SALAZAR, N. B. Tourism Imaginaries: a conceptual approach. Annals of Tourism Research, v. 39, n. 2, 2012, p. 863-882.

SANTOS JÚNIOR, A. P.; SANTOS, A. C. F. Arte e turismo: a fotografia como ferramenta de trabalho do turismólogo contemporâneo. Revista Eletrônica Aboré. ISSN 1980-6930, 2007. 
SECRETARIA DE TURISMO DE PERNAMBUCO. Disponível em: http://www.pe.gov.br/secretarias/secretariade-turismo-esportes-e-lazer/. Acesso em: 15 jun. 2016.

SILVA, J. M. As tecnologias do imaginário. Porto Alegre: 2. ed. Sulina, 2006.

SOARES, T. C. Características do Turismo de Experiência: estudos de caso em Belo Horizonte e Sabará sobre inovação e diversidade na valorização dos clientes. Minas Gerais - UFMG, 2009.

SONIASTRAVELS. Soniatravels - youtube. Disponível em: https://www.youtube.com/user/ soniastravels>. . Acesso em: 31 dez. 2016.

SUN TUNG, V. W.; RITCHIE, J. R. B. Exploring the essence memorable tourism experiences. Annals of Tourism Research, v. 38, n. 4, 2011, p. 1367-1386.

TAN, S.; KUNG, S.; LUH, D. A Model of "Creative Experience" in creative tourism. Annals of Tourism Research, v. 41, 2013, p. 153-174.

TRIGO, L. G. G. A viagem como experiência significativa. In: PANOSSO NETTO, A.; GAETA, C. C. Turismo de Experiência. São Paulo: Senac, 2010.

URIELY, N. The tourist experience, conceptual developments. Annals of Tourism Research. V. 32, n. 1, p. 199-216, 2005.

URRY, J. The tourist gaze. London, Sage, 1990.

COELHO, A. M.; RIBEIRO, L. M.; FONTES FILHO, J. R. A Experiência como vantagem competitiva para o turismo. Fundação Getúlio Vargas - FGV, 2007.

MA, J. et al. Customer delight from theme park experience: the antecedents of delight based on cognitive appraisal theory. Annals of Tourism Research, v. 42, 2013, p. 359-381.

\section{Notas}

[1] O artigo é uma versão mais recente e aperfeiçoada de um artigo apresentado no XIII Seminário ANPTUR 2016. A atual versão traz novos autores e discussões mais abrangentes sobre a temática estudada.

[2] A sociedade dos sonhos proposta por Rolf Jensen é uma era voltada ao emocional e espiritual. O autor revela que a tendência com relação à "comercialização de emoções" é ter seu valor material subordinado aos valores espirituais, emocionais e simbólicos. Essa tendência já é aplicada atualmente em produtos e serviços relacionados a entretenimento, como, por exemplo, parques temáticos (NASCIMENTO; MAIA; DIAS, 2012; SOARES, 2009).

[3] The Experience Economy (A Economia da Experiência) é um livro escrito por Joseph Pine e James Gilmore (Ver Referências) em que é argumentado que cada negócio fechado com um cliente precisa ser um evento memorável e que essa memória (experiência) é o que se configurará como o produto da transação.

[4] The Dream Society (A Sociedade dos Sonhos) é um livro escrito por Rolf Jensen (Ver Referências) que explica a transformação da sociedade da "informação" para uma sociedade dos "sonhos".

[5] Este termo representa uma já existente, porém, pouco articulada, forma de resultado econômico. Funciona como uma alternativa para a competitividade estratégica à frente dos conceitos de oferta e demanda baseados em valores que, oriundos dos tempos de produção em massa, se apoiam demasiadamente no binômio menor custo e menor preço (PINE, 1994). Promove crescimento econômico aliado à informação em forma de serviços, produtos ou experiência propriamente dita. Para o turismo, o tema representa uma nova forma de articulação entre as constantes mudanças de mercado, o crescimento tecnológico e a satisfação das necessidades dos clientes (COELHO; RIBEIRO; FONTES FILHO, 2007).

[6] Commodities significa, em português, mercadorias. No mercado financeiro o termo refere-se às transações de matériaprima, agrícola ou mineral, que possui grande importância para a economia internacional. Trata-se de recursos fundamentais para a produção industrial e o consumo de uma economia, sendo considerados, portanto, itens essenciais.

[7] A estratégia de "preços Premium" envolve a fixação de um preço maior que os produtos semelhantes do mercado, devido a uma percepção alta de valor agregado ao seu produto despertando o desejo nas pessoas.

[8] A sociedade da imagem, que a autora Susana Gastal aborda em seu livro "Turismo, Imagens e Imaginários", não se trata apenas da estetização do que está à sua volta, mas também a saturação por sofisticados acervos de memórias disponibilizadas pela fotografia, pelo cinema e pela televisão, criando "museus imaginários" pessoais que agem quando as pessoas entram em contato com novos produtos culturais. 
Fabíola Fernandes Silva, et al. Imagem e Imaginário como componentes da construção da Experiênci...

[9] “A Sociedade do Espetáculo" é um livro do marxista francês Guy Debord, que teve sua publicação em 1967 com o título original La Société du Spectacle (Ver Referências). Trata-se de um livro crítico e teórico sobre o consumo, a sociedade e o capitalismo. O autor volta-se a compreender as imagens na sociedade, buscando entender sobre o fetichismo da mercadoria. Debord procura abordar a alienação da sociedade por meio da espetacularização dos espaços. 